\title{
Microbial community study of the iron ore concentrate of the Sishen Iron Ore Mine, South Africa
}

\author{
P. J. Williams ${ }^{1}$ and T. E. Cloete ${ }^{1}$ \\ 1 Department of Microbiology and Plant Pathology, Faculty of Natural and \\ Agricultural Sciences, University of Pretoria, Pretoria, 0002, South Africa
}

\section{Abstract}

As a result of the advancing global technologies and civilisation, there has been a progressive depletion of high-grade mineral deposits. Consequently, it has become increasingly important to process lower-grade ores. Phosphorous (P) and particular potassium $(\mathrm{K})$ contained in the iron ore concentrates of the Sishen Iron Ore Mine have a detrimental effect on the steel making process, whereby these alkali's cause cracks to form in the refractory lining of blast furnaces. It is initially essential to determine which microbes are indigenously present at the Sishen Iron Ore Mine before strategising how best to employ them to industrial advantage. Therefore, the objective of this study was to determine which microorganisms are indigenous to the iron ore and soil of the Sishen Iron Ore Mine. The bacterial 16S PCR and fungal ITS PCR revealed several bacterial and fungal species present in the mine environment. The bacterial isolates were found to be closely related to Herbaspirillum species, as well as Acidithiobacillus ferrooxidans, while the fungal isolates were closely related to Aureobasidium pullulans, Phaeosphaeria nodorum, Aspergillus fumigatus, and Candida parapsilosis. Isolating A. fumigatus from the iron ore/soil of the mine may indicate that $A$. niger, the most common fungi used for the production of citric acid, can adapt to the stringent mine environment. This would allow the application of $A$. niger for the production of citric acid, which may be used for the chemical leaching of the $\mathrm{P}$ and $\mathrm{K}$ from the iron ore concentrate of the Sishen Iron Ore Mine. 


\section{Introduction}

The depletion of high quality iron ore $(>60 \% \mathrm{Fe} ;<0.24 \% \mathrm{~K})$ deposits necessitates processing of lower quality iron ore ( $<60 \% \mathrm{Fe} ;>0.24 \% \mathrm{~K})$ (Jian and Sharma 2004; Corne Taljaard, personal communication). Elements such as phosphorous (P) and potassium (K) contained within the lower quality iron ore concentrates have a detrimental effect on steel making process, leading to penalties charged by the steel processing plants when purchasing iron ore concentrates containing high concentrations of $\mathrm{P}$ and $\mathrm{K}$ (Yusfin et al. 1999). In an attempt to minimise these penalties charged by the steel making companies, low quality ore concentrates has been blended with high quality iron ore concentrates to "dilute" the P and $\mathrm{K}$ in the export iron ore concentrate of the mine (Dukino et al. 2000). This has also been the practice in Hamersley, Australia, where low-P iron ore $(0.05 \% \mathrm{P})$, being the major component, was blended with high-P iron ore $(0.10 \% \mathrm{P})$ before export to the steel making companies (Dukino et al. 2000). However, the low quality iron ore stockpiles of the Sishen Iron Ore Mine are increasing, and it is therefore essential to develop an economical, environmentally friendly process to treat the iron ore concentrates that contain high concentrations of $\mathrm{P}$ and $\mathrm{K}$.

Microorganisms are capable of converting nutrients in their surrounding environment to biochemical compounds, such as organic acids, required for their metabolism (Gupta and Sharma 2002; Lesniak et al. 2002). The processes by which this happens can be invaluable when applied in industrial practice. For example, Acidithiobacillus ferrooxidans and A. thiooxidans are capable of converting ferrous sulphate $\left(\mathrm{FeSO}_{4}\right)$ to ferric sulphate $\left[\mathrm{Fe}_{2}\left(\mathrm{SO}_{4}\right)_{3}\right]$, while producing sulphuric acid $\left(\mathrm{H}_{2} \mathrm{SO}_{4}\right)$ (Glazer and Nikaido 1995; Rawlings 2002). Ferric sulphate and $\mathrm{H}_{2} \mathrm{SO}_{4}$ both play an important role during the overall leaching of certain minerals from ore bodies (Glazer and Nikaido 1995). Ferric sulphate is a strong oxidising agent, which is reduced to ferrous sulphate $\left(\mathrm{FeSO}_{4}\right)$, leading to the oxidation of certain insoluble metal sulphides to the corresponding soluble metal sulphate (Glazer and Nikaido 1995). Sulphuric acid is responsible for maintaining the low $\mathrm{pH}$ in the environment in order to maintain the optimal metabolic activity of the bacteria in the system (Glazer and Nikaido 1995). 
It is plausible that microbes indigenously present in the iron-ore and surrounding soil are able to utilise $\mathrm{P}$ and $\mathrm{K}$ in their membrane and cell wall as structural components, as well as in many other microbiological metabolic processes. It is hypothesised that microbes already living and growing in soils and iron-ore at the Sishen mine are capable of this metabolism since their environment favours the appropriate required conditions. The purpose of this investigation was to determine which microbes are indigenously present in the iron ore and soil of the Sishen Iron Ore Mine before strategising how best to employ them to industrial advantage. To date no information regarding the microbial community present in the iron ore concentrates and soil of the Sishen Iron Ore Mine exists.

Some microorganisms are difficult to culture due to their different growth requirements and physiology, limiting simultaneous cultivation of several species (Widmer et al. 1999). Denaturing gradient gel electrophoresis (DGGE) is an ideal molecular method for monitoring microbial community ecology since it is PCR based and does not employ classical methods of culturing the microbes within a sample. DGGE relies on variation in genetic sequence of a specific amplified region to differentiate between species within microbial communities (Banks and Alleman 2002; Koizumi et al. 2002). By determining the closest relatives of unknown microorganisms, the known characteristics can be inferred upon them (Ueda et al. 1995). Most commonly, 16S rRNA genes are used to give an overall indication of the bacterial species composition of a sample, while the Internal Transcribed Spacer region (ITS) is used in the case of fungal species composition.

\section{Materials and methods}

\section{Sample selection}

Iron ore concentrate samples (export product) were received for bacterial community analysis from the Sishen Iron Ore Mine. In addition, iron ore mixed with soil was collected at various locations within the mine for fungal community analysis. 


\section{Bacterial isolation}

Iron ore samples were prepared for DNA extraction by enrichment cultures. Briefly, the enrichment cultures consisted of $100 \mathrm{~g}$ of iron ore inoculated into 11 of Nutrient Broth (Sigma-Aldrich Chemie GmbH, Buchs, Switzerland) in 21 Erlenmeyer flasks. The flasks and their contents were incubated at $25^{\circ} \mathrm{C}$ for $24 \mathrm{~h}$. The resulting suspension was used for DNA extraction.

\section{Fungal isolation}

Fungi were isolated from the soil/iron ore by adding $100 \mathrm{~g}$ of each sample to $100 \mathrm{ml}$ of sterile distilled water $\left(\mathrm{dH}_{2} \mathrm{O}\right)$ in a different $500 \mathrm{ml}$ Erlenmeyer flask. The flasks and their contents were incubated at $25^{\circ} \mathrm{C}$ for $48 \mathrm{~h}$. One millilitre of the suspension was plated onto $20 \mathrm{~g} \mathrm{l}^{-1}$ water agar (Merck, Darmstadt, Germany) in $60 \mathrm{~mm}$ Petri-dishes (Concorde Plastics, Johannesburg, South Africa). The Petri-dishes were incubated at $25^{\circ} \mathrm{C}$ and monitored at $24 \mathrm{~h}$ intervals for fungal spore formation. Single fungal spores were then selected and transferred onto half-strength Potato Dextrose Agar (PDA) (Merck) in $60 \mathrm{~mm}$ Petri-dishes (Concorde Plastics). The Petri-dishes were incubated at $25^{\circ} \mathrm{C}$ for approximately 2 weeks.

\section{Bacterial DNA extraction}

Bacterial DNA of each morphologically distinct colony was extracted separately from the enrichment culture suspensions using the CTAB method (Doyle and Doyle 1987; Cullings 1992). Briefly, $1.5 \mathrm{ml}$ of culture suspension was centrifuged to form a compact pellet, followed by the discarding of the supernatant. The pellet was resuspended in $567 \mu l$ of Tris-EDTA (TE) buffer. Thirty microlitres of Sodium Dodecyl Sulphate (SDS) and $3 \mu \mathrm{l}$ of Proteinase $\mathrm{K}\left(20 \mathrm{mg} \mathrm{l}^{-1}\right)$ was added and mixed, followed by incubation at $37^{\circ} \mathrm{C}$ for $1 \mathrm{~h}$. After incubation $100 \mu \mathrm{l}$ of $5 \mathrm{M}$ Sodium Chloride $(\mathrm{NaCl})$ was added and mixed thoroughly, followed by the addition of $80 \mu \mathrm{l}$ of the $\mathrm{CTAB} / \mathrm{NaCl}$ solution. The contents of the tubes were mixed thoroughly and incubated at $65^{\circ} \mathrm{C}$ for $10 \mathrm{~min}$. This was followed by mixing with an equal volume of chloroform/isoamyl alcohol, followed by centrifuging for $5 \mathrm{~min}$. The supernatant was transferred to a new Eppendorf tube, followed by mixing with an equal volume of phenol/chloroform/isoamyl alcohol and 
centrifugation for $5 \mathrm{~min}$. The supernatant was transferred to a new Eppendorf tube, followed by DNA precipitation by the addition of a 0.6 volume of isopropanol. The DNA precipitate was collected by centrifugation for $15 \mathrm{~min}$. The precipitated DNA was washed with $70 \%$ ethanol to remove the residual $\mathrm{CTAB}$ and salts, followed by centrifugation to form a pellet of DNA. The supernatant was discarded and the DNA allowed to dry in a vacuum dryer. The DNA was dissolved in $100 \mu \mathrm{l}$ of TE and stored at $-20^{\circ} \mathrm{C}$ for molecular analysis.

\section{Fungal DNA extraction}

DNA of each morphologically distinct colony was extracted separately from the fungal cultures using the sterile river sand method (Surridge et al. 2003). Briefly, fungal mycelium was placed in Eppendorf tubes, followed by the addition of sterile river sand to facilitate the disruption of the mycelia wall. Five hundred microlitres of DNA extraction buffer (DEB) was added to each tube and the samples grinded. A further $200 \mu 1$ of DEB was added to each tube, followed by mixing of the samples in each tube. This was followed by the addition of $500 \mu \mathrm{l}$ of phenol and $300 \mu \mathrm{l}$ of chloroform, after which the tubes were vortexed. The tubes were centrifuged at $1000 \mathrm{rpm}$ for $60 \mathrm{~min}$, followed by transferring of the upper aqueous phase to a new Eppendorf tube. Five hundred microlitres of phenol and $500 \mu \mathrm{l}$ of chloroform was added to each tube, followed by centrifugation at 10,000 rpm for $10 \mathrm{~min}$. This phenol/chloroform step was repeated until the interphase was clean. The upper aqueous phase was transferred to a new Eppendorf tube, followed by the addition of $500 \mu \mathrm{l}$ of chloroform. The tubes were centrifuged at 11,000 rpm for $5 \mathrm{~min}$, and the resulting aqueous phase transferred to a new Eppendorf tube. Twice the volume of $100 \%$ ethanol was added and mixed, followed by incubation at $4^{\circ} \mathrm{C}$ overnight. The tubes were centrifuged at $11,000 \mathrm{rpm}$ for $30 \mathrm{~min}$ and the supernatant discarded. The pellet containing DNA was washed by adding $500 \mu \mathrm{l}$ of $70 \%$ ethanol, followed by centrifugation at 11,000 rpm for $5 \mathrm{~min}$. The supernatant was removed and the tubes containing the DNA vacuum dried for $30 \mathrm{~min}$. The DNA was dissolved in $100 \mu \mathrm{l}$ of sterile Sabax water and stored at $-20^{\circ} \mathrm{C}$ for molecular analysis. 


\section{S polymerase chain reaction for amplification of bacterial DNA}

A $16 \mathrm{~S}$ polymerase chain reaction (PCR) was performed by amplifying a portion of the 16S eubacterial gene from the bacterial DNA extracted from the enriched culture suspensions. The following primers were used for DNA amplification:

K: PRUN518r: 5'-ATT-ACC-GCG-GCT-GCT-GG-3' (Siciliano et al. 2003)

M: PA8f-GC: 5'-CGC-CCG-CCG-CGC-GCG-GCG-GGC-GGG-GCG-GGG-GCA-CGGGGG-GAG-AGT-TTG-ATC-CTG-GCT-CAG-3' (Fjellbirkeland et al. 2001).

All PCR reagents were manufactured by Bio-Rad Laboratories (Hercules, CA, USA), unless otherwise stated. The PCR reaction was performed in a reaction volume of $25 \mu 1$ containing, $150 \mathrm{mM} \mathrm{KCl}, 30 \mathrm{mM}$ Tris- $\mathrm{HCl}$ (pH 9.0), 0.3\% Triton X-100, $50 \mathrm{mM} \mathrm{MgCl}$, $10 \mu \mathrm{M}$ PCR nucleotide mix, 5 pmol primer PRUN518r (Whitehead Scientific, Cape Town, South Africa), 5 pmol primer PA8f-GC (Whitehead Scientific), 1.5 units of Taq polymerase and $0.5 \mu \mathrm{l}$ bacterial suspension. Denaturation of extracted DNA at $95^{\circ} \mathrm{C}$ for 10 min was followed by 35 cycles of denaturation at $94^{\circ} \mathrm{C}$ for $30 \mathrm{~s}$, annealing at $51^{\circ} \mathrm{C}$ for $30 \mathrm{~s}$, and extension at $72^{\circ} \mathrm{C}$ for $1 \mathrm{~min}$ (Bio-Rad Thermal Cycler, Bio-Rad Laboratories). A final extension at $72^{\circ} \mathrm{C}$ for 10 min concluded the PCR amplification of the DNA. A reaction containing no DNA template was included as a negative control. The amplified PCR products were separated using 1\% agarose gel electrophoresis in Tris-AcetateEDTA (TAE) buffer.

\section{Denaturing gradient gel electrophoresis}

The 16S PCR products were subjected to DGGE according to the method described by Muyzer et al. (1993). Briefly, $10 \mu$ l containing ca. $250 \mathrm{ng}$ of the $16 \mathrm{~S}$ PCR products was loaded per lane onto a $25-55 \%$ denaturing gradient gel. The gel was run at $70 \mathrm{~V}$ for $17 \mathrm{~h}$ at a constant temperature of $60^{\circ} \mathrm{C}$. Image analysis was performed using the $\mathrm{Gel} 2 \mathrm{~K}$ program and fingerprints were analysed in a cluster investigation using CLUST. 


\title{
Internal transcribed spacer region PCR for amplification of fungal DNA
}

A portion of the ITS gene sequence of the DNA from each fungal isolate was subjected to PCR using the following primer set (White et al. 1990):

\section{ITS1: 5'-CAT-CGA-GAA-GTT-CGA-GAA-GG-3' \\ ITS4: 5'-TAC-TTG-AAG-GAA-CCC-TTA-CC-3'.}

\begin{abstract}
All PCR reagents were manufactured by Bio-Rad Laboratories (Hercules, CA, USA), unless otherwise stated. The PCR reaction was performed in a reaction volume of $25 \mu \mathrm{l}$ containing, $150 \mathrm{mM} \mathrm{KCl}, 30 \mathrm{mM}$ Tris- $\mathrm{HCl}\left(\mathrm{pH}\right.$ 9.0), 0.3\% Triton X-100, $50 \mathrm{mM} \mathrm{MgCl}_{2}$, $10 \mu \mathrm{M}$ PCR nucleotide mix, 5 pmol primer ITS1 (Whitehead Scientific, Cape Town, South Africa), 5 pmol primer ITS4 (Whitehead Scientific), 1.5 units of Taq polymerase and $0.5 \mu \mathrm{l}$ bacterial suspension. Denaturation of extracted DNA at $92^{\circ} \mathrm{C}$ for 10 min was followed by 30 cycles of denaturation at $92^{\circ} \mathrm{C}$ for $1 \mathrm{~min}$, annealing at $50^{\circ} \mathrm{C}$ for $1 \mathrm{~min}$, and extension at $72^{\circ} \mathrm{C}$ for $1 \mathrm{~min}$ (Bio-Rad Thermal Cycler, Bio-Rad Laboratories). A final extension at $72^{\circ} \mathrm{C}$ for 10 min concluded the PCR amplification of the DNA. A reaction containing no DNA template was included as a negative control. The amplified PCR products were separated using $1 \%$ agarose gel electrophoresis in Tris-Acetate-EDTA (TAE) buffer.
\end{abstract}

\section{Sequence analysis of the bacterial and fungal DNA from the iron ore/soil}

Sequencing the PCR products from the 16S PCR and ITS PCR using the K and ITS1 primers above, respectively, provided tentative species identification. Each isolate was sequenced in an Eppendorf tube containing $1 \mu \mathrm{l}$ of clean PCR product, $2 \mu \mathrm{l}$ "Big Dye" (Roche) sequence mix, $0.32 \mu \mathrm{l}$ primer and $1.68 \mu \mathrm{l}$ filter-sterilised $\mathrm{dH}_{2} \mathrm{O}$. The sequence PCR products were cleaned by the addition of $15 \mu \mathrm{l}$ of sterile $\mathrm{dH}_{2} \mathrm{O}$, followed by the transfer of the entire volume to a $0.5 \mu 1$ Eppendorf sequencing tube. Two microlitres of $3 \mathrm{M}$ sodium acetate and $50 \mu \mathrm{l}$ of $95 \%$ ethanol were added to each sequencing tube and allowed to stand on ice for $10 \mathrm{~min}$, followed by centrifugation at 10,000 rpm for $30 \mathrm{~min}$. The supernatant was removed, followed by washing of the DNA with $150 \mu$ of $70 \%$ 
ethanol. After centrifugation at 10,000 rpm for $5 \mathrm{~min}$, the supernatant was aspirated and the DNA pellet vacuum dried for $10 \mathrm{~min}$. DNA sequences were determined using the ABI PRISM ${ }^{\mathrm{TM}}$ Dye Terminator Cycle Sequencing Ready Reaction Kit using AmpliTaq ${ }^{\circledR}$ DNA Polymerase (Applied Biosystems, UK). Partial sequences of the 16S eubacterial gene, as well as of the ITS region of the rDNA of the bacteria and fungi, respectively, were obtained using the K and ITS1 primers, respectively. Nucleotide sequence order was confirmed by comparison with the sequences obtained from the M and ITS4 primers, respectively, of the corresponding samples. The sequences reported in this study were compared to similar sequences present in the GenBank database by using the BLAST program of the National Center for Biotechnology Information (http://www.ncbi.nlm.nih.gov), and matching hits, with e-values closest to 0.0 indicating an exact match, were selected for alignment. Sequences were aligned with the CLUSTALX version 1.83 program (Thompson et al. 1997) and inserted gaps were treated as missing data. Ambiguously aligned regions were excluded from the data set before analysis. Phylogenetic trees were generated using the CLUSTALX version 1.83 program. The robustness of the trees was determined by bootstrap resampling of the multiple-sequence alignments (1000 sets) with the CLUSTALX version 1.83 program. The graphical output of the phylogenetic trees was created with the TREEVIEW version 1.6.6 program (University of Glasgow; http://taxonomy.zoology.gla.ac.uk).

\section{Results and discussion}

The DNA extracted from the iron ore enrichment cultures using the CTAB method proved to be of a high quality, displaying no protein and no RNA contamination (Fig. 1). The 16S PCR of the DNA extracted from the iron ore enrichment cultures yielded a ca. $500 \mathrm{bp}$ band on a $1.5 \%$ TAE agarose gel (Fig. 2). 


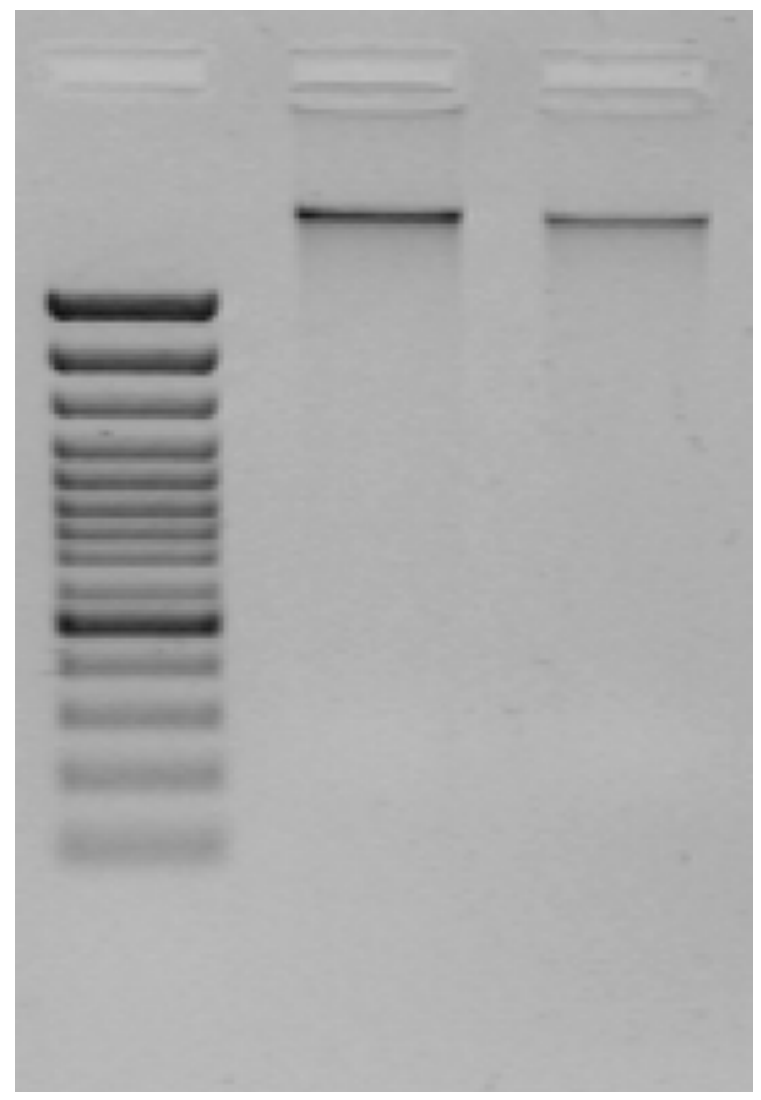

Fig. 1 A 1.5\% TAE agarose gel showing DNA extracted from two iron-ore samples using the CTAB method

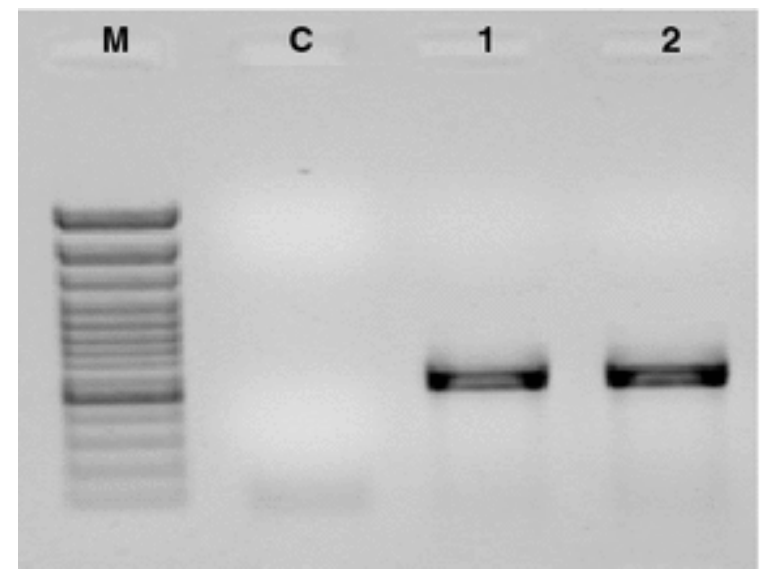

Fig. 2 A 1.5\% TAE agarose gel showing 16S PCR products of ca. $500 \mathrm{bp}$ (M, $100 \mathrm{bp}$ DNA marker; C, negative control; 1 and 2, iron ore samples 
The DGGE with the 16S rDNA PCR products from the duplicate iron ore enriched samples resulted in a gel displaying a similar banded fingerprint pattern with some higher colour intensity (Fig. 3). This duplication indicated reproducibility of results on DGGE gels and that some bacterial species within the sample form the dominant portion of the population indicated by darker banding (Fig. $\underline{3}$ ). Each band on the gel is theoretically representative of only one distinct species.

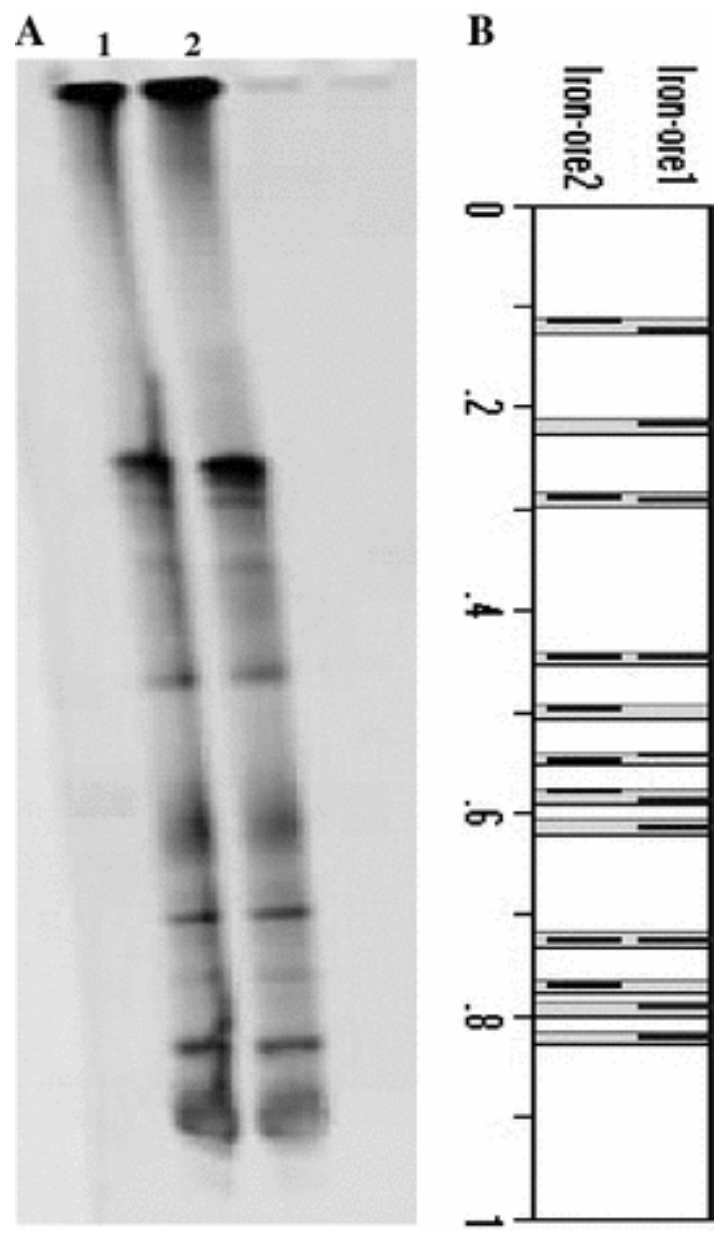

Fig. 3 (a) Denaturing gradient gel fingerprints resulting from assessing bacterial diversity between communities detected from iron-ore samples, using a gradient of $25-55 \%$; (b) graphic representation of the denaturing gradient gel determining bacterial community richness and diversity

The DGGE gel showed clear multiple banding, forming a fingerprint, in each lane. However, only 12 bands were observed across both of the duplicate samples run, 
indicating 12 bacterial species present. This is most probably due to the extreme environment of the iron ore. Two dense, dominant bands were displayed in both of the duplicate fingerprints, which indicated that these species are prominent in the iron ore. According to phylogeny and blast results these bands were both closely related to Herbaspirillum species (Fig. 4).

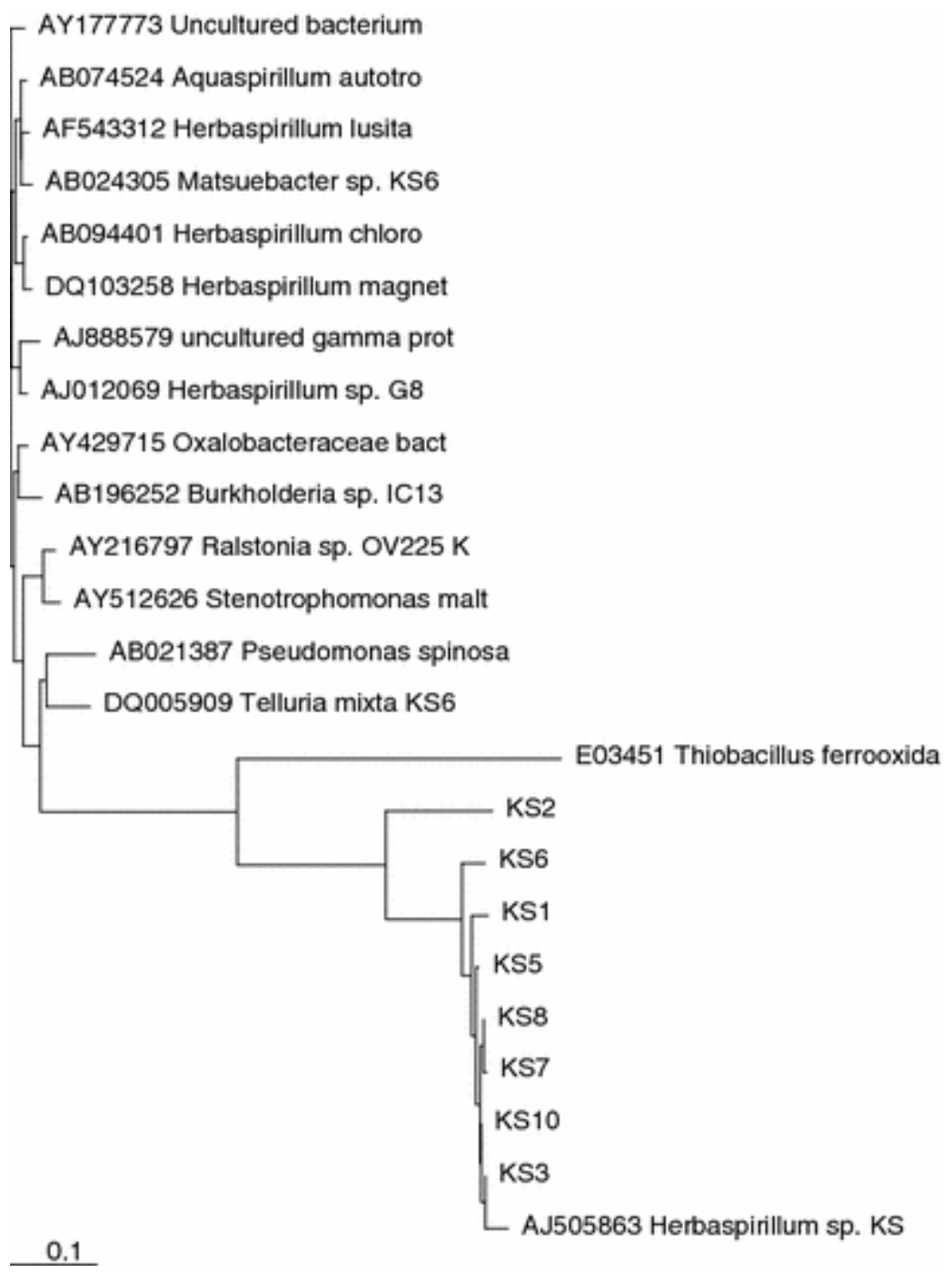

Fig. 4 Phylogenetic analysis of the 16S Eubacterial gene of the rDNA operon of the bacteria isolated from the enriched iron ore concentrate of the Sishen Iron Ore Mine Many of the Herbaspirillum species are known to be soil inhabitants associated with iron ore soils or extremophiles associated with chlorophenol degradation (Im et al. 2003; 
Connon et al. 2005). According to literature linked to blast results on GenBank, Herbaspirillum magnetovibrio is an example of a novel magnetotactic bacterial species found in iron ore soil (Gao et al. 2005). One of their chief functions is nitrogen fixation and root nodule formation in nutrient limited soils (Kniemeyer et al. 1999; Probian et al. 2003; Valverde et al. 2003). All but one of the sequences found in the enriched iron ore concentrate were close matches to Herbaspirillum species, while KS2 is a closer match to A. ferrooxidans (formerly known as Thiobacillus ferrooxidans) (Fig. 4). It seems that most of the species present in the sample are to be expected in iron ore and its surrounding soils.

The most likely candidate for bioleaching is A. ferrooxidans. This bacterial species is well known for its bioleaching properties, and is widely used in the industry for this purpose. A. ferrooxidans is acknowledged as being responsible for iron and inorganic sulphur compound oxidation in areas such as mine tailings and coal deposits (Horan 1999). A. ferrooxidans is assumed to be obligately aerobic, however, under anaerobic conditions it can be grown on elemental sulphur using ferric iron as an electron acceptor (Das et al. 1992; Pronk et al. 1992; Ohmura et al. 2002). It has been documented that At. ferrooxidans could also obtain energy from oxidising $\mathrm{Cu}^{+}, \mathrm{Se}^{2-}$, tetrathionate, molecular hydrogen, formic acid, antimony compounds, uranium compounds, and molybdenum compounds (Horan 1999). Thus, A. ferrooxidans can be considered a facultative anaerobe that plays an important role within iron and sulphur cycles in acidic environments such as in the mining industry (Horan 1999). This ability to grow in oxygen deficient environments implies useful biotechnology in bioleaching processes where anaerobic conditions may exist.

DNA was successfully extracted from all fungal pure cultures isolated from the iron ore/soil of the Sishen Iron Ore Mine. The ITS PCR DNA extracted from the fungal pure cultures yielded a ca. $700 \mathrm{bp}$ fragment of PCR product on a 1.5\% TAE agarose gel (Fig. 5). 


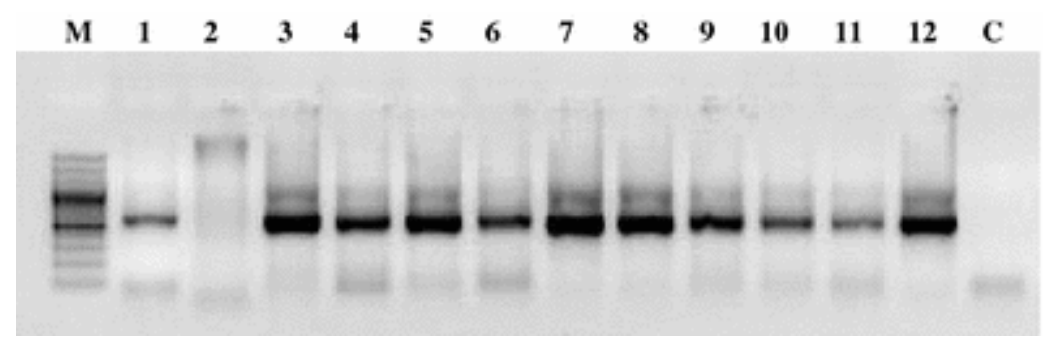

Fig. 5 A 1.5\% TAE agarose gel showing the ITS PCR products of ca. $700 \mathrm{bp} \mathrm{(M,} 100 \mathrm{bp}$ DNA marker; 1-12, fungal culture PCR amplicons; C, negative control)

The phylogenetic analysis of the ITS gene of the fungi isolated from the iron ore/soil of the mine is illustrated in Fig. 6. The phylogenetic analysis indicated that one of the fungal isolates (KIOL1) from the iron ore/soil had a strong sequence comparison with Aureobasidium pullulans, while another fungal isolate (KIOL2) had a strong sequence comparison with Aspergillus fumigatus (Fig. 6). The fungal isolates KIOL4 and KIOL6, as well as KIOL3 and KIOL5 were found to be similar to one another, having strong sequence comparisons to Phaeosphaeria nodorum and Candida parapsilosis, respectively (Fig. 6). 


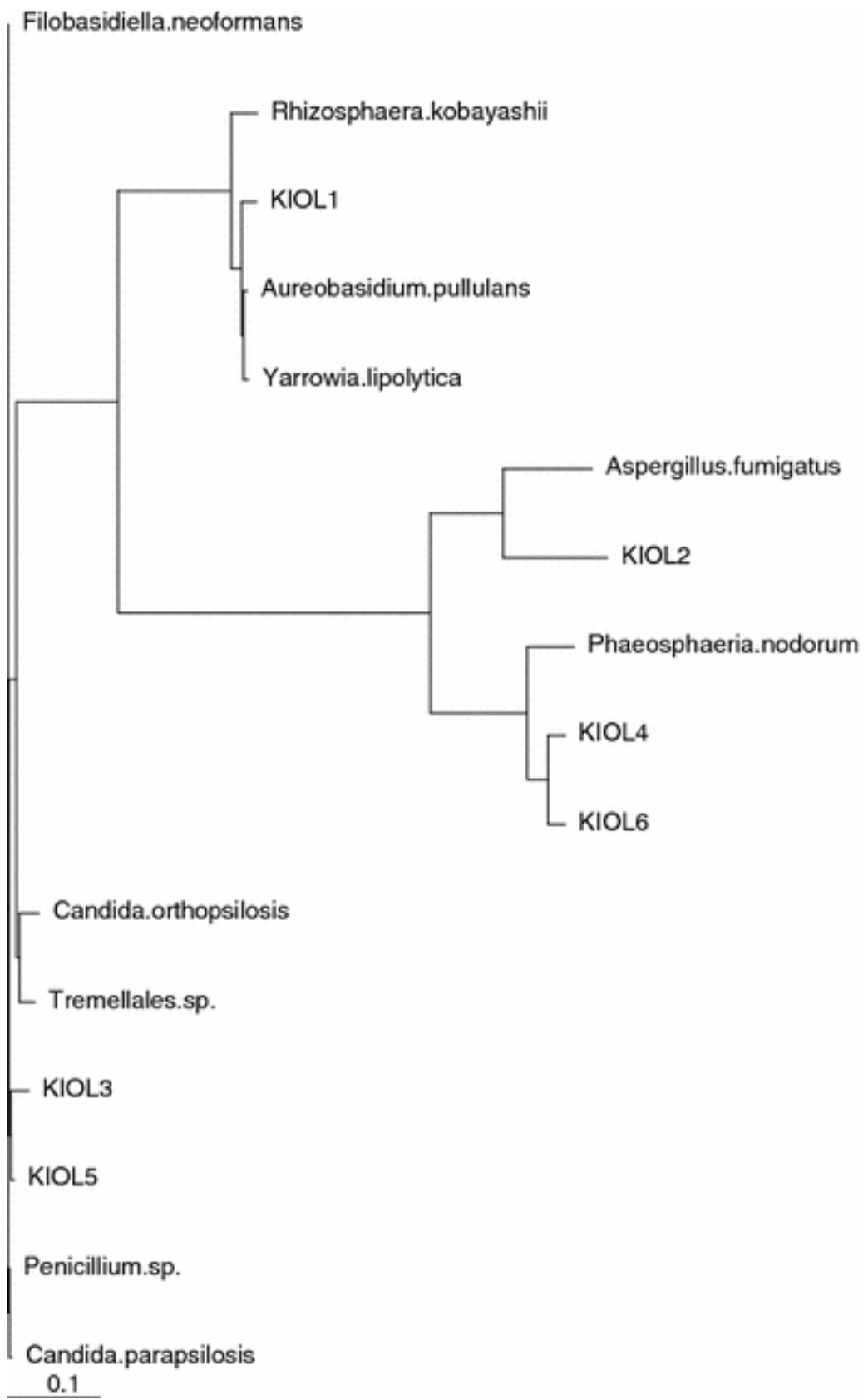

Fig. 6 Phylogenetic analysis of the ITS gene of the fungi isolated from the iron ore/soil of the Sishen Iron Ore

Aureobasidium pullulans is a dimorphic fungus, which is commonly distributed throughout the environment, especially in soil and plants (Krogh et al. 1998; Yoshikawa et al. 2006). This fungus is able to grow well in the presence of high concentrations of saccharides, and produces polysaccharides (pullulans and $\beta$-glucan), oligosaccharides 
(FOS and isomaltooligosaccharides) and various carbohydrate-degrading enzymes (Deshpande et al. 1992; Yun et al. 1994; Hamada et al. 2000). A. pullulans may be a potential candidate for bioremediation of heavy metal contaminated environments, as this fungus has been shown to assimilate certain heavy metals, such as zinc, cobalt, cadmium and copper (Gadd et al. 1987; Krogh et al. 1998). Furthermore, A. pullulans has been used for the commercial production of xylanases, used for the enzyme-aided bleaching in the pulp and paper industry (Viikari et al. 1994).

Aspergillus fumigatus is frequently found in the environment, especially soil, and the fungus is able to be airborne in the form of conidia (Goto et al. 1998; Weig et al. 2001; Pastor et al. 2006). Humans frequently inhale the conidia of $A$. fumigatus, however, only a small proportion of the exposed individuals develop clinical manifestations (Weig et al. 2001). The most susceptible individuals suffer from immunosuppression, caused by therapeutics, leukopenia or chronic granulomatous disease, resulting in invasive pulmonary or disseminated aspergillosis (Weig et al. 2001). Another human pathogen, Candida parapsilosis, has emerged as an important cause of human candidiasis, often responsible for pathological lesions of the nails (Gautret et al. 2000; Krcmery and Barnes 2002; Kiffer-Moreira et al. 2007). In addition, the heterothallic ascomycete, Phaeosphaeria nodorum, is a common necrotrophic plant pathogen causing leaf blotch and glume blotch diseases on wheat (Triticum aestivum) (Lalaoui et al. 2000; Stukenbrock et al. 2006). Neither A. fumigatus nor C. parapsilosis or P. nodorum have been reported to have industrial biotechnology application potential.

The most likely candidate for the removal of $\mathrm{P}$ and $\mathrm{K}$ from the iron ore concentrate would seem to be $A$. ferrooxidans, however, this bacterium produces sulphuric acid, which is undesired in the iron ore industry due its corrosive properties. Furthermore, the $\mathrm{P}$ and $\mathrm{K}$ contained in the iron ore is in a non-sulphidic phase, and therefore, the use of organic acids, such as citric acid, for the removal of these contaminants may have potential (Rawlings 2005). These organic acids are typically produced by certain types of fungi, such as Aspergillus niger (Jianlong 2000; Vandenberghe et al. 2000; Rawlings 2005). Although A. niger was not isolated from the iron ore/soil of the Sishen Iron Ore Mine, 
isolating A. fumigatus may indicate that $A$. niger may have the potential to adapt to the environment that prevails at the mine. This would allow the application of A. niger for the production of citric acid, which in turn may be used for the removal of $\mathrm{P}$ and $\mathrm{K}$ from the iron ore concentrate.

\section{References}

Banks MK, Alleman J (2002) Microbial indicators of bioremediation potential and success. In: Hazardous substance research centres. Georgia Tech Research Corporation. http://www.hsrc.org/mw-microbial.html. Cited 24 Oct 2007

Connon SA, Tovanabootr A, Dolan M, Vergin K, Giovannoni SJ, Semprini L (2005) Bacterial community composition determined by culture-independent and -dependent methods during propane-stimulated bioremediation in trichloroethene-contaminated groundwater. Environ Microbiol 7(2):165-178. doi:10.1111/j.1462-2920.2004.00680.x

Cullings KW (1992) Design and testing of a plant-specific PCR primer for ecological and evolutionary studies. Mol Ecol 1:233-240. doi:10.1111/j.1365-294X.1992.tb00182.x

Das A, Mishra AK, Roy P (1992) Anaerobic growth on elemental sulfur using dissimilar iron reduction by autotrophic Thiobacillus ferrooxidans. FEMS Microbiol Lett 97:167172. doi:10.1111/j.1574-6968.1992.tb05457.x

Deshpande MS, Rale VB, Lynch JM (1992) Aureobasidium pullulans in applied microbiology: a status report. Enzyme Microb Technol 14:514-527. doi:10.1016/01410229(92) 90122-5

Doyle JJ, Doyle JL (1987) A rapid DNA isolation procedure for small quantities of fresh leaf tissue. Phytochem Bull 19:11-15 
Dukino RD, England BM, Kneeshaw M (2000) Phosphorous distribution in BIF-derived iron ores of Hamersley Province, Western Australia. Trans Instn Min Metall (Sect B Appl Earth Sci) 109:B168-B176

Fjellbirkeland A, Torsvik V, Øvreås L (2001) Methanotrophic diversity in an agricultural soil as evaluated by denaturing gradient gel electrophoresis profiles of pmoA, mxaF and 16S rDNA sequences. Antonie Van Leeuwenhoek 79:209-217.

doi:10.1023/A:1010221409815

Gadd GM, White C, Mow JLII (1987) Heavy metal uptake by intact cells and protoplasts of Aureobasidium pullulans. FEMS Microbiol Lett 45:261-267. doi:10.1111/j.15746968.1987.tb02375.x

Gao M, Liu P, Liu Y, Dai S, Peng K, Xie W (2005) A novel magnetotactic bacterial species, Herbaspirillum magnetovibrio from iron ore soil. GenBank accession number: DQ103258. National Center for Biotechnology Information. http://www.ncbi.nlm.nih.gov. Cited 22 Oct 2007

Gautret P, Rodier MH, Kauffmann-Lacroix C, Jacquemin JL (2000) Case report and review. Onychomycosis due to Candida parapsilosis. Mycoses 43:433-435. doi:10.1111/j.1439-0507.2000.00602.x

Glazer AN, Nikaido H (1995) Application of biotechnology for mineral processing. In: Microbial biotechnology: fundamentals of applied microbiology. Freeman, New York, pp 268-287

Goto CE, Barbosa EP, Kistner LCL, Moreira FG, Lenartocicz V, Peralta RM (1998) Production of amylase by Aspergillus fumigatus utilizing $\alpha$-methyl-D-glycoside, a synthetic analogue of maltose, as substrate. FEMS Microbiol Lett 167:139-143 
Gupta S, Sharma CB (2002) Biochemical studies of citric acid production and accumulation by Aspergillus niger mutants. World J Microbiol Biotechnol 18:379-383. doi:10.1023/A:1015521506052

Hamada N, Deguchi K, Ohmoto T, Sakai K, Ohe T, Yoshizumi H (2000) Ascorbic acid stimulation of production of a highly branched $\beta$-1, 3-glucan by Aureobasidium pullulans K-1-oxalic acid, a metabolite of ascorbic acid as the stimulating substance. Biosci Biotechnol Biochem 64:1801-1806. doi:10.1271/bbb.64.1801

Horan J (1999) Thiobacillus ferrooxidans. Colorado school of mines, Golden, Colorado. http://www.mines.edu/fs_home/jhoran/ch126/thiobaci.htm. Cited 24 Oct 2007

Im WT, Bae HS, Yokota A, Lee ST (2003) Herbaspirillum chlorophenolicum sp. nov., a 4-chlorophenol-degrading bacterium. Int J Syst Evol Microbiol 54(Pt 3):851-855. doi:10.1099/ijs.0.02812-0

Jian N, Sharma DK (2004) Biohydrometallurgy for non-sulphidic minerals - a review. Geomicrobiol J 21:135-144. doi:10.1080/01490450490275271

Jianlong W (2000) Enhancement of citric acid production by Aspergillus niger using ndodecane as an oxygen vector. Proc Biochem 35:1079-1083

Kiffer-Moreira T, De Sá Pinheiro AA, Alviano WS, Barbosa FM, Souto-Padrón T, Nimrichter L et al (2007) An ectophosphatase activity in Candida parapsilosis influences the interaction of fungi with epithelial cells. FEMS Yeast Res 7:621-628. doi:10.1111/j.1567-1364.2007.00223.x

Kniemeyer O, Probian C, Rossello-Mora R, Harder J (1999) Anaerobic mineralization of quaternary carbon atoms: isolation of denitrifying bacteria on dimethylmalonate. Appl Environ Microbiol 65(8):3319-3324 
Koizumi Y, Kelly JJ, Nakagawa T, Urakawa H, El-Fantroussi S, Al-Muzaini S et al (2002) Parallel characterisation of anaerobic toluene- and ethylbenzene-degrading microbial consortia by PCR-denaturing gradient gel electrophoresis, RNA-DNA membrane hybridisation, and DNA microarray technology. Appl Environ Microbiol 68:3215-3225. doi:10.1128/AEM.68.7.3215-3225.2002

Krcmery V, Barnes AJ (2002) Non-albicans Candida spp. causing fungaemia: pathogenicity and antifungal resistance. J Hosp Infect 50:243-260. doi:10.1053/jhin.2001.1151

Krogh N, Olson J, Jensen B, Reeslev M (1998) Uptake of $\mathrm{Zn}^{2+}$ by yeast and mycelial growth of Aureobasidium pullulans grown in chemostat culture. FEMS Microbiol Lett 163:249-253. doi:10.1111/j.1574-6968.1998.tb13053.x

Lalaoui F, Halama P, Dumortier V, Paul B (2000) Cell wall-degrading enzymes produced in vitro by isolates of Phaeosphaeria nodorum differing in aggressiveness. Plant Pathol 49:727-733. doi:10.1046/j.1365-3059.2000.00491.x

Lesniak W, Pietkiewicz J, Podgorski W (2002) Citric acid fermentation from starch and dextrose syrups by a trace metal resistant mutant of Aspergillus niger. Biotechnol Lett 24:1065-1067. doi:10.1023/A:1016030513270

Muyzer G, De Waal EC, Uitterlinden AG (1993) Profiling of complex microbial populations by denaturing gradient gel electrophoresis analysis of polymerase chain reaction-amplified genes coding for 16S rRNA. Appl Environ Microbiol 59:695-700

Ohmura N, Sasaki K, Matsumoto N, Saiki H (2002) Anaerobic respiration using $\mathrm{Fe}^{3+}, \mathrm{S}^{0}$, and $\mathrm{H}_{2}$ in the chemolithoautotrophic bacterium Acidithiobacillus ferrooxidans. $\mathrm{J}$ Bacteriol 184:2081-2087. doi:10.1128/JB.184.8.2081-2087.2002 
Pastor A, Gafa V, Boutonnat J, Grillot R, Ambroise-Thomas P, Aldebert D (2006)

Intracellular oxidative response of human monocytes and granulocytes to different strains of Aspergillus fumigatus. Mycoses 49:73-79. doi:10.1111/j.1439-0507.2006.01188.x

Probian C, Wulfing A, Harder J (2003) Anaerobic mineralization of quaternary carbon atoms: isolation of denitrifying bacteria on pivalic acid (2, 2-dimethylpropionic acid). Appl Environ Microbiol 69(3):1866-1870. doi:10.1128/AEM.69.3.1866-1870.2003

Pronk JT, De Bruyn JC, Bos P, Kuenen JG (1992) Anaerobic growth of Thiobacillus ferrooxidans. Appl Environ Microbiol 58:2227-2230

Rawlings DE (2002) Heavy metal mining using microbes. Annu Rev Microbiol 56:6591. doi:10.1146/annurev.micro.56.012302.161052

Rawlings DE (2005) Characteristics and adaptability of iron- and sulfur-oxidizing microorganisms used for the recovery of metals from minerals and their concentrates. Microb Cell Fact 4:13-27. doi:10.1186/1475-2859-4-13

Siciliano SD, Germida JJ, Banks K, Greer CW (2003) Changes in microbial community composition and function during a polyaromatic hydrocarbon phytoremediation field trial. Appl Environ Microbiol 69:483-489. doi:10.1128/AEM.69.1.483-489.2003

Stukenbrock EH, Banke S, McDonald BA (2006) Global migration patterns in the fungal wheat pathogen Phaeosphaeria nodorum. Mol Ecol 15:2895-2904

Surridge AKJ, Viljoen A, Crous PW, Wehner FC (2003) Identification of the pathogen associated with Sigatoka disease of banana in South Africa. Plant Pathol 32:27-31. doi:10.1071/AP02058

Thompson JD, Gibson TJ, Plewniak F, Jeanmougin F, Higgins DG (1997) The CLUSTAL X windows interface: flexible strategies for multiple sequence alignment 
aided by quality analysis tools. Nucleic Acids Res 25:4876-4882.

doi:10.1093/nar/25.24.4876

Ueda T, Suga Y, Matsuguchi T (1995) Molecular phylogenetic analysis of a soil microbial community in a soybean field. Eur J Soil Sci 46:415-421. doi:10.1111/j.13652389.1995.tb01337.x

Valverde A, Velazquez E, Gutierrez C, Cervantes E, Ventosa A, Igual JM (2003)

Herbaspirillum lusitanum sp. nov., a novel nitrogen-fixing bacterium associated with root nodules of Phaseolus vulgaris. Int J Syst Evol Microbiol 53(Pt 6):1979-1983. doi:10.1099/ijs.0.02677-0

Vandenberghe LPS, Soccol CR, Pandey A, Lebeault JM (2000) Solid-state fermentation for the synthesis of citric acid by Aspergillus niger. Biores Technol 74:175-178

Viikari L, Kantelinen A, Sundquist J, Linko M (1994) Xylanases in bleaching: from an idea to the industry. FEMS Microbiol Rev 13:335-350. doi:10.1111/j.15746976.1994.tb00053.x

Weig M, Reichard U, Groß U (2001) Aspergillus fumigatus_-virulence and opportunism? Mycoses 44:351-355. doi:10.1046/j.1439-0507.2001.00670.x

White TJ, Bruns T, Lee S, Taylor J (1990) PCR protocols. In: Innis MA, Gelfand DH, Sninsky JJ, White TJ (eds) Amplification and direct sequencing of fungal ribosomal RNA genes for phylogenetics. Academic Press, London, pp 315-322

Widmer F, Shaffer BT, Porteous LA, Seidler RJ (1999) Analysis of nifH gene pool complexity in soil and litter at a Douglas fir forest site in the Oregon cascade mountain range. Appl Environ Microbiol 65:374-380 
Yoshikawa J, Amachi S, Shinoyama H, Fujii T (2006) Multiple $\beta$-fructofuranosidases by Aureobasidium pullulans DSM2404 and their roles in fructooligosaccharide production. FEMS Microbiol Lett 265:159-163. doi:10.1111/j.1574-6968.2006.00488.x

Yun JW, Lee MG, Song SK (1994) Continuous production of isomalto-oligosaccharides from maltose syrup by immobilized cells of permeabilized Aureobasidium pullulans. Biotechnol Lett 16:1145-1150. doi:10.1007/BF01020841

Yusfin YS, Chernousov PI, Garten V, Karpov YA, Petelin AL (1999) The role of alkali's and conserving resources in blast-furnace smelting. Metallurgist 43:54-58. doi:10.1007/BF02463518 